DOI https://doi.org/10.30525/978-9934-26-000-1-33

\title{
СУЧАСНА РЕКЛАМА ЯК МАРКЕР СТАВЛЕННЯ ДО ЛІТНІХ ЛЮДЕЙ В УКРАЇНСЬКОМУ СУСПІЛЬСТВІ
}

\author{
Фєдотова Н. М. \\ кандидатка філологічних наук, \\ доцентка кафедри маркетингу \\ Лук'янченко С. А. \\ здобувачка спечіальності «Журналістика» \\ Національний університет харчових технологій \\ м. Київ, Україна
}

Трансформація гуманістичної парадигми у світовому співтоваристві в епоху глобалізації неминуче призводить до змін ціннісних детермінант суспільства кожної країни. Своєрідним маркером соціокультурних змін виступає масовокомунікативний процес, зокрема реклама, яка найбільше відтворює стереотипи його учасників.

За мету дослідження ми поставили відстеження реалізації образу літніх людей в українській рекламі як прояв реалізації принципу біологічної рівності у світоглядній концепції нового гуманізму.

Стереотипне ставлення до літніх людей склалося ще за часів радянського минулого, лише утверджувалося на пострадянському просторі та існує й сьогодні. Зокрема, І. Вялкова й К. Шендеровський, надаючи в лекції «Висвітлення у ЗМІ прав літніх людей» рекомендації для майбутніх працівників засобів масової інформації, зазначають: «Образ літніх людей у ЗМІ найчастіше подано стереотипно. Для літніх людей, зображуваних у ЗМІ, характерні фізична і розумова слабкість, погане здоров'я; дратівливість і невдоволення в міжособистісних відносинах; стереотипні обов'язки і заняття - в основному вони пенсіонери i домогосподарки; зовнішня непривабливість» [1, с. 194]. Подібна думка висловлюється й О. Березіною: «У сучасному суспільстві образ старості носить, у більшості, негативний характер. Вважається, що особам літнього й, особливо, похилого віку властиві такі риси, як: негативізм, консерватизм, інертність, упертість, запальність, підвищена уразливість, егоїзм, дратівливість, дріб'язковість, скнарість та ін.» [2]. Авторка стверджує, що ЗМІ поширюють негативний образ старості, чим сприяють утвердженню стереотипів щодо старості в молодого покоління, а це зі свого боку призводить до поширення ейджизму та геронтофобії в суспільстві. Однак наші спостереження за тенденціями, які простежуються в сучасній рекламі, доводять протилежне. Рекламні ролики останніх 2-3 років демонструють трансформацію образу літніх людей у бік толерантності й прийняття. Зазначимо, що наразі не лише в рекламі українські пенсіонери перестають бути відсталою і неактивною суспільною групою. Вони продовжують працювати й ведуть активний 
спосіб життя, хоча й багато в чому дотримуються традиційної соціальної ролі - ведення домашнього господарства, робота на присадибній ділянці, догляд за онуками тощо.

Просування образу активної, позитивно налаштованої й обізнаної на сучасні техніці літньої людини відбувається зокрема в рекламних роликах мобільного оператора «Київстар». Наприклад, руйнування стереотипу, що літні люди не розуміються на техніці, відбувається в рекламному ролику 2016 р. із ключовою фразою «Ну і гад же ти, Валєрчик», яка стала крилатою після виходу ролика через дотепне обігравання омонімічної пари «гад же ти» і «гаджети». У ролику 2017 р. «Одеса-мама»у відеорекламі простих тарифів від «Київстар» зображено позитивну бабусю, яка на прохання дочки співає по телефону для свого онука. Літня жінка в ролику не соромиться демонструвати свій талант, співаючи на балконі для всієї вулиці. У ролику цього ж мобільного оператора від 2018 р. під час рекламування міжнародних дзвінків зіставляється стереотипний образ літньої жінки, яка боїться витратити зайве, та жінки, яка розуміється на тарифах оператора, тому вільно телефонує в Італію до своїх родичів.

Отже, «Київстар» як бренд-лідер не стільки продає свій товар, скільки формує систему людських цінностей (піклування про близьких, необмежені можливості кожної людини), що зокрема руйнує стереотип образу літньої людини.

Інші торгові марки також транслюють у рекламних роликах змінені образи літніх людей. Наприклад, у ролику торгової марки Garage «Granny’s anti Compote», хоч і обіграється стереотип, що бабуся варить компоти, робить консервацію на зиму й піклується про харчування онуків, але вона приїжджає на рожевому ретромобілі сучасно вдягнена й розуміється на молодіжних трендах.

Трансформований образ літнього чоловіка спостерігаємо в рекламі девелоперського проєкту Києва Signature (2016 р.), який розповідає, що варто мріяти й втілювати свої мрії. Комічний ролик торгової марки Kresko (2018 p.) - це монолог університетського викладача у віці, який розповідає про свої улюблені снеки. У ролику торгової марки «Аптека садівника» (2018 р.) демонструється взаємодопомога різних поколінь родини під час садових робіт без традиційного нав'язування стереотипу, що город і сад - це для пенсіонерів. Реклама заправок Wog «Там, де люди» (2020р.) демонструє знайомство літніх чоловіка й жінки в поїзді, заперечуючи стереотип, що стосунки можуть зароджуватися тільки в молодому віці. Мережа магазинів «Фокстрот»у рекламі кредитів на 25 платежів (2020 р.) показує серед покупців усміхненого сивобородого чоловіка на моноколесі із планшетом у руках, який з легкістю здійснює покупки. Реклама мобільного оператора «Водафон» (2017 р.) побудована на сюжеті, у якому онука допомагає дідусеві побачити світ за допомогою відеозв'язку. Такий ролик руйнує стереотип самотньої старості. Мережа «Укртелеком» як образ-персонаж представила чоловіка у віці, який самостійно підключив інтернет-телебачення і тому 
танцює біля телевізора (2020 р.). У рекламі представлено активний образ-персонаж, спроможний до налаштування техніки.

Показ старості в такому ракурсі сприяє нівеляції ейджизму як соціально-психологічного феномену, оскільки, по-перше, рекламні персонажі сприймаються споживачами без стереотипної упередженості й негативу, по-друге, цільова аудиторія такої реклами - це люди у віці, які, дивлячись цю рекламу, переймають зразок поведінки, утверджуючись у своїх можливостях. Така взаємокореляція образів і призводить до поступового руйнування стереотипу.

Однак у заявленої проблеми є й ще один бік - геронтофобія. Показ моложавих людей у віці, які залишаються активними й повними енергії, одночасно із ламанням стереотипів про знедолене існування літніх людей нав'язує хибний образ старості. Варто визнати, що з віком в організмі неминуче відбуваються незворотні процеси - хвороби, погіршення зору, старіння шкіри тощо. Боязнь таких перетворень призводить до депресії.

Виходом є демонстрація способів подолання болю, коригування образу та можливості прийняття своєї зміненої зовнішності. Прикладом врівноваженого образу літньої людини є персонажі реклами медичних препаратів. Швидкість подолання проблем демонструється в рекламі крему для фіксації зубних протезів «Корега» (2018 р.) «Я знову можу свистіти». Літні люди в рекламі мазі «Живокост» (2018р.) підказують, як швидко впоратися із болем в суглобах. У рекламі мазі «Вольтарен» 2017 р. від імені кота й 2019 р. від особи собаки демонструються наслідки їі застосування людьми у віці й набуття ними колишньої активності. Глюкометр One Touch рекламує вчителька, якій 62 роки (2017р.) Вона розповідає, як легко можна контролювати цукор у крові й залишатися активною. Ведучий програми «Миколина погода» Микола Луценко радить використовувати таблетки «Неофлорум» проти розладу травлення. В усіх згаданих роликах ми бачимо прийом успішного використання рекламованого товару споживачами й позбавлення їх від болю.

Наведені приклади дають можливість дійти висновку про утвердження гуманістичних позицій в українській соціальній сфері, зокрема в соціокомунікативному просторі, і поступове руйнування усталених стереотипів та соціальних міфів щодо літніх людей.

\section{Література:}

1. Вялкова I., Шендеровський К. Висвітлення у ЗМІ прав літніх людей. Права людини та мас-медіа в Украӥні: Збірник конспектів лекиій / за ред. Виртосу I., Шендеровського К. Київ: Інститут журналістики КНУ ім. Тараса Шевченка. 2018. С. 190-195.

2. Березіна О. Ейджизм у суспільстві: проблеми пізнього віку. Психологічна теорія $i$ технологія навчання. Вип. 5 / за ред. С. Д. Максименка, Смульсон М. Л. Київ, 2008. URL: http:// www.psy-science.com.ua/department/zbirnyk-2008. (дата звернення: 20.11.2020) 